Revista de Crítica Literaria Latinoamericana So Journal of Latin American Literary Criticism

\title{
Reseña. Marcos Rosenzvaig. Cabeza de tigre. La patria que nos robaron. Buenos Aires. Marea, 2017.
}

Cuando nos acercamos a la novela histórica que retrata climas epocales complejos como el universo de la emancipación continental, nos hundimos en varias problemáticas que se suceden alrededor de los procesos de ficcionalización de la historia: las consabidas cuestiones referidas a la verosimilitud, la configuración de las figuras heroicas y de un discurso criollo, las asociaciones de la gesta decimonónica con arcaicas representaciones escolares enraizadas en la memoria, por ejemplo.

La novela Cabeza de Tigre. La patria que nos robaron (2017), del dramaturgo, ensayista y novelista tucumano Marcos Rosenzvaig nos invita a navegar por estas problemáticas completando el trayecto que se inicia con Perder la cabeza. Los amores que la historia no perdonó (1998), cuya tercera reedición corregida circulará en julio de 2018 y que versa sobre la decapitación de Marco Avellaneda. Y continúa con Monteagudo. Anatomía de una revolución (2016), que fue publicada en el marco del Bicentenario de la Declaración de la Independencia Argentina y pone en diálogo los restos del héroe zambo con un forense que, cien años después de su muerte, procura dilucidar si posee ascendencia afro o indígena. Con esta trilogía —que recupera aquellos episodios, personajes y espacios 
históricos que, si bien son reconocibles, no forman parte de los relatos centrales de la gesta emancipatoria - el autor entusiasma a los lectores invitándoles a desandar caminos. Así, se evidencia que, entre retóricas y climas epocales, está cifrada la identidad nacional y que los avatares de la contemporaneidad argentina pueden explicarse en matrices conformadas en la larga duración.

Tres historias se entrelazan en un mismo espacio -Cabeza de Tigre, paraje que se encuentra entre Córdoba y Santa Fe, que se llamará luego Los Surgentes-. Tres historias se entretejen en el relato de José Antonio Grimau que, como buen "cuentero", transmite a sus hijos el "cuento" de la familia y de la patria, tramitando así la memoria personal y la nacional. La primera sucede en 1810 y es quizá la historia por la que todos conocemos la existencia y la relevancia de Cabeza de Tigre, relevancia por la que - incluso - se ha producido un filme homónimo en el 2001, dirigido por Claudio Etcheverry: nos referimos al fusilamiento de Santiago de Liniers. La segunda también acontece durante el periodo emancipatorio, un poco después, en 1817, y quizás nos resulta la más novedosa porque es, tal vez, la menos conocida. Pero, sin duda, es la más relevante porque articula las diferentes temporalidades de la novela: se trata del robo de las Actas de la Independencia a Cayetano Grimau y Galvez, el chasqui de la Independencia, luego de una emboscada comandada por el Inglés García, soldado de Artigas. La tercera historia forma parte de la aún convulsionada memoria reciente. Sucede en 1976, en el mismo lugar que conserva su signo de desgracia con un nuevo nombre: "Los Surgentes". Entonces y allí, se produce el fusilamiento de siete militantes montoneros.

Las tres historias que ficcionalizan diferentes episodios históricos se engarzan en la cadencia del relato de José Antonio Grimau, descendiente de Cayetano, quien en un presente - en el que siguen batallando diversas versiones de la memoria nacional - busca inicialmente la venganza y, con ella, el desagravio: en primer lugar, busca resarcir la historia de Cayetano rescatando las Actas de la Independencia robadas y ajusticiando a los descendientes del crimen. Este rescate significa recuperar la legitimidad de la emancipación nacional pues, como dice el 
protagonista, "Ningún pueblo puede ser libre con una partida de nacimiento trucha. Yo, José Antonio Grimau, tengo el mandato de devolverle a este pueblo asaltado su dignidad" (Rosenzvaig, Cabeza de Tigre 151).

De algún modo, el robo de las Actas — quizá por ese poder performativo que tiene la palabra escrita tan bien capturado en la noción de la ciudad letrada (Ángel Rama, 1984) — ha significado el arrebato de una identidad nacional que, como la silueta de los desaparecidos, precisa ser encontrada para lograr su "reparación". Hablamos aquí de "reparación", no de la venganza inicial ni de armoniosas reconciliaciones. De esa forma, la memoria del chasqui o mensajero que sobrevivió al robo, pero sucumbió ante la deshonra de un juicio y de una muerte por fiebre amarilla - y, por ende, la memoria de su familia, puedan reivindicarse en el camino de José Antonio, quien busca un lugar en los anales heroicos de la patria. Así, el protagonista emprende el camino del héroe.

En segundo lugar, como un nuevo chasqui, José Antonio en su itinerario de desagravios busca reclamar otro robo más próximo, un arrebato identitario: el de la familia de su esposa Ana. Su madre se incorpora a la novela en el personaje de Diana, a través de la ficcionalización de una octava fusilada en Los Surgentes. De esta manera, Ana queda en su temprana adolescencia doblemente despojada: por una parte, de los bienes materiales de su familia que han sido apropiados por los militares; por otra, de los bienes afectivos pues queda huérfana y a expensas de los peligros y las violencias propias de la vida en la calle. La de Ana — al igual que la de José Antonio, cuyo padre se suicida - es la historia de la orfandad. Los huérfanos de la dictadura que dolientes remiendan vidas maltrechas para continuar:

Quizás, pensó, dos huérfanos de alma podrían completar algo. Pero no fue así, porque esas heridas no cicatrizan nunca. Llevan la infección de la verdad escondida. José Antonio tenía miedo de que las heridas supuraran hablando, y Ana confiaba que la tierra las cubriría. (169) 
Pero la herida de las identidades y los destinos robados — la de una nación sin acta de nacimiento y la de una joven huérfana - solo podrán suturarse en el camino de desagravio que emprende José Antonio cuando se condensa en la figura de Cayetano. De este modo, se convierte en un nuevo chasqui y en un héroe vengador, las figuras de José Antonio y Cayetano se superponen, al igual que las temporalidades, para refundar, reparar así el derrotero de la patria huérfana:

Él debió hacer lo que estoy haciendo ahora. Soy él, pero muero como un héroe, sin extender décadas y décadas inútiles para sucumbir en la deshonra de la fiebre amarilla. ¡Yo ajusticié a un traidor de la patria! ¡Yo soy el verdadero Cayetano Grimau! (14)

Cabeza de Tigre, como bien lo sugirió Noé Jitrik a propósito de su presentación, supera al género "novela histórica" y se enmarca en la tradición de la literatura de viaje. Sin duda, el camino de José Antonio, chasqui y héroe, busca más que vengar - "reparar" los robos familiares y nacionales para reescribir la historia. Una historia que se reescribe también con la incorporación de quienes han sido olvidados en los relatos criollos que procuran el "blanqueamiento" de la nación. Así, podemos verlo con la referencia al mestizaje, tema escamoteado por la novela histórica argentina y reservado para los países hispanoamericanos de ascendencia indígena; la referencia a los quechua y los aymara hablantes, a partir de un personaje muy interesante como lo es Nuna quien, si bien es amada por Cayetano, será luego abandonada y sustituida por una esposa criolla; la referencia a la figura de Güemes y su accionar militar que, como Monteagudo, no goza del mismo renombre que otros referentes del panteón heroico decimonónico.

Una historia que se ficcionaliza escapándose del artificioso corsé genérico supuesto en la clasificación "novela histórica". Cabeza de Tigre se aleja de las categorías que la preceden y lo hace con lirismo, con diálogos signados por el magistral uso del registro dramatúrgico y con exquisitos guiños metatextuales. Se aleja de las variables establecidas para la novela histórica y para un sistema literario 
argentino que presume seguir un derrotero diferente al del resto del continente. Se aleja para encontrar un espacio único y propio: el de una escritura que experimenta y ficcionaliza echando mano tanto de procedimientos poéticos como de los teatrales.

Cabeza de tigre es entonces, más que una novela histórica, un camino o una indagación poética sobre los procesos identitarios familiares y nacionales. Como lo sugiere el mismo narrador, que aparece hacia el final del relato, Cabeza de Tigre —el paraje, pero también la escritura - se erige como una "metáfora" de la Argentina o como un Aleph; es decir, un prisma desde el que el narrador - $-\mathrm{y}$ también, el lector- se acerca o se aleja para ver la historia nacional. En esta ineludible referencia borgeana vemos cómo, en tono metatextual, la novela entabla diálogo no sólo con las referencias históricas de la nación sino también con el sistema literario argentino, con sus aristas más eruditas y más populares: así discurren a lo largo del relato las referencias al Gauchito Gil, el Martín Fierro, Don Segundo Sombra, la Pachamama o Rodolfo Walsh.

Y con el mismo acento borgeano y el tono metatextual, hacia el final se incorpora la figura de la "biblioteca" y el "archivo", a partir del relato de Pablo: un narrador en primera persona que, durante el retorno de la democracia, se ha topado con el registro de los fusilados de Los Surgentes, con el anaquel rotulado Las Actas perdidas de la Independencia, con unas cartas históricas, con un documento que ordenaba el fusilamiento de Liniers. Y tiembla la mano de este narrador cuando descubre cómo estos episodios se conectan en un mismo espacio. En pocas palabras, las temporalidades simultáneas que conviven en un mismo territorio, superponiendo diferentes memorias, se suceden en Cabeza de Tigre, lugar que se conforma como metáfora o Aleph. Y allí, entre tiempos trenzados, se enlazan las memorias de una patria que ha sido asaltada de diversas maneras desde su nacimiento.

Cabeza de Tigre es un Aleph, del mismo modo que la escritura de Rosenzvaig puede ser un prisma desde el que los lectores curiosos, que escarban los estantes de novedades en las librerías, siguen pensando en tiempos 
yuxtapuestos, en las batallas de la memoria y en los caminos de reivindicación. Quizá así, a través del prisma de la ficcionalización, los lectores pueden zarpar hacia nuevas reflexiones que den un poco de sosiego en estos convulsionados tiempos. 